\title{
Stance Classification Post Kesehatan di Media Sosial Dengan FastText Embedding dan Deep Learning
}

\author{
Ernest Lim, Teknologi Informasi ISTTS, Esther Irawati Setiawan, Teknologi Informasi ISTTS, dan Joan \\ Santoso, Teknologi Informasi ISTTS
}

\begin{abstract}
Abstrak - Misinformasi merupakan fenomena yang semakin sering terjadi di media sosial, tidak terkecuali Facebook, salah satu media sosial terbesar di Indonesia. Beberapa penelitian telah dilakukan mengenai teknik identifikasi dan klasifikasi stance di media sosial Indonesia. Akan tetapi, penggunaan Word2Vec sebagai word embedding dalam penelitian tersebut memiliki keterbatasan pada pengenalan kata baru. Hal ini menjadi dasar penggunaan fastText embedding dalam penelitian ini. Dengan menggunakan pendekatan deep learning, penelitian berfokus pada performa model dalam klasifikasi stance suatu judul post kesehatan di Facebook terhadap judul post lainnya. Stance berupa for (setuju), observing (netral), dan against (berlawanan). Dataset terdiri dari 3500 judul post yang terdiri dari 500 kalimat klaim dengan enam kalimat stance terhadap setiap klaim. Model dengan fastText pada penelitian ini mampu menghasilkan F1 macro score sebesar $64 \%$.
\end{abstract}

Keywords-Bahasa Indonesia, Deep Learning, fastText, Media Sosial, Stance Classification

\section{Pendahuluan}

$\mathrm{P}$ enyebaran informasi lewat media sosial memiliki sifat yang berbeda dari penyebaran di dunia nyata. Aspek komunikasi media sosial sangat dipengaruhi oleh fenomena echo chamber [1], [2]. Bentuk umum dari fenomena ini adalah kepercayaan user terhadap suatu informasi bila informasi tersebut sejalan dengan keyakinan politik user [3]. Dengan demikian, misinformasi ataupun hoax menyebar dengan cepat di sosial media, seperti Facebook [4]. Selain itu, aspek bot juga turut membantu penyebaran hoax secara signifikan [5]. Hal ini berdampak pada berbagai masalah penting seperti pemilu [6], penanganan konflik dan krisis [7], dan penanganan wabah [8].

Pada kasus Zika, rumor dibagikan tiga kali lebih banyak dibanding berita yang terverifikasi, meskipun sudah terdapat sosialisasi di media sosial. Kelemahan strategi komunikasi ini disebabkan oleh situasi yang selalu berkembang secara cepat sehingga banyak informasi yang beredar dan mengurangi visibilitas informasi kesehatan yang benar [9].

Oleh sebab itu, penting untuk dilakukan identifikasi dan

Ernest Lim, Teknologi Informasi, Institut Sains dan Teknologi Terpadu Surabaya, Surabaya, Jawa Timur, Indonesia (e-mail: ernest1@mhs.stts.edu)

Esther Irawati Setiawan, Teknologi Informasi, Institut Sains dan Teknologi Terpadu Surabaya, Surabaya, Jawa Timur, Indonesia (e-mail: esther@stts.edu)

Joan Santoso, Teknologi Informasi, Institut Sains dan Teknologi Terpadu Surabaya, Surabaya, Jawa Timur, Indonesia (e-mail: joan@stts.edu) klasifikasi hoax, terutama di bidang kesehatan. Pendekatan dalam klasifikasi hoax pada umumnya hanya klasifikasi konten. Akan tetapi, media sosial memberikan peluang untuk meneliti stance classification dengan banyaknya data yang tersedia, seperti profil user hingga interaksi pada post.

Stance classification adalah teknik untuk mengetahui secara otomatis pandangan penulis teks terhadap suatu statement, apakah mendukung, menentang, atau netral [10]. Proses stance classification secara umum dapat dibagi menjadi dua tahap, yaitu: pembentukan vektor kata dan klasifikasi stance. Dalam pembentukan vektor kata, banyak penelitian stance classification yang menggunakan Word2Vec untuk embedding. Popularitas Word2Vec ini dikarenakan kemampuannya dalam mengetahui similaritas makna antar kata. Informasi similaritas ini didapatkan dengan memperhatikan kesamaan kata-kata di sekitar kata target [11].

Pada tahap klasifikasi, Convolutional Neural Network (CNN) termasuk salah satu classifier yang populer untuk stance classification. CNN pertama kali digunakan oleh Collobert untuk mengambil fitur penting secara otomatis [12]. Informasi hirarki fitur ini didapatkan melalui operasi max-over-time pooling yang dikembangkan lebih lanjut oleh Kim untuk klasifikasi kalimat [13]. Namun, banyak juga metode klasifikasi stance yang menggunakan LSTM. Tren ini disebabkan oleh kemampuan LSTM dalam menyimpan informasi sekuens kata dalam kalimat [14].

Dalam konteks bahasa Indonesia, penelitian stance classification pada umumnya menggunakan Word2Vec, seperti pada penelitian [15] dan classifier LSTM [16]. Hal ini dapat menyebabkan hasil klasifikasi yang kurang akurat karena faktor kesalahan pengetikan. Oleh karena itu, peneliti mengusulkan penggunaan fastText saat pembentukan vektor kata dan kalimat dan menggunakan deep learning, terutama Bi-LSTM, untuk menghitung probabilitas stance.

Usulan tersebut mengacu pada penelitian [16] yang mampu menghasilkan model yang cukup akurat dengan menggunakan Word2Vec dan classifier LSTM. Pemilihan fastText sendiri berdasarkan kepada kelebihan fastText saat membaca kata. Dengan $n$-gram character, sebuah kata akan dibaca per karakter sesuai nilai n-gram tersebut [17]. Dengan demikian, permasalahan Out-of-Vocabulary words (OOV) dapat teratasi. Bi-LSTM sendiri dipilih karena terbukti lebih akurat dan tidak serentan LSTM untuk overfitting [18]. Peneliti juga memilih CNN karena proses pembelajaran yang membutuhkan relatif sedikit epoch dan 
mampu menghasilkan akurasi yang tinggi [19] dan LSTM karena selain menjadi dasar perbandingan dengan penelitian Setiawan [16], LSTM terbukti tepat untuk permasalahan teks yang berhubungan dengan sekuens [20].

Tujuan dari penelitian ini adalah menemukan pendekatan dan parameter stance classification yang efektif untuk membantu klarifikasi hoax di media sosial. Secara khusus, peneliti mencari kombinasi metode dan pengaturan parameter dalam penggunaan fastText dan deep learning untuk klasifikasi stance yang paling akurat.

\section{PENElitian TERKAIT}

Penelitian mengenai stance, seperti terlihat pada Tabel I, banyak yang menggunakan word embedding Word2Vec dan classifier CNN dan LSTM.

TABEL I

Penelitian Stance Detection dan Classification

\begin{tabular}{|c|c|c|c|}
\hline Topik & Riset & Pendekatan & Hasil \\
\hline $\begin{array}{c}\text { Stance } \\
\text { Classification }\end{array}$ & $\begin{array}{l}\text { Chen, } \\
2016\end{array}$ & $\begin{array}{l}\text { Pemodelan CNN } \\
+ \text { fitur akun media } \\
\text { sosial (jumlah } \\
\text { like, comment) }\end{array}$ & $\begin{array}{c}\text { Model } \\
\text { memberikan } \\
\text { hasil akurasi } \\
\text { tertinggi } \\
\text { dibanding tanpa } \\
\text { informasi } \\
\text { tambahan dari } \\
\text { medsos }\end{array}$ \\
\hline $\begin{array}{c}\text { Stance } \\
\text { Classification }\end{array}$ & $\begin{array}{c}\text { Kochkina } \\
\text {, } 2017\end{array}$ & $\begin{array}{c}\text { Pemodelan } \\
\text { kalimat rata-rata } \\
\text { W2V + jumlah } \\
\text { kata negatif + } \\
\text { classifier } \text { LSTM }\end{array}$ & $\begin{array}{c}\text { Pendekatan } \\
\text { memenangkan } \\
\text { SemEval } 2017 \\
\text { Task 8 Sub- } \\
\text { task A }\end{array}$ \\
\hline $\begin{array}{c}\text { Stance } \\
\text { Classification }\end{array}$ & $\begin{array}{c}\text { Lozano, } \\
2017\end{array}$ & $\begin{array}{c}\text { POS Tagging } \\
\text { W2V + fitur akun } \\
\text { Twitter }+ \\
\text { handwritten rules } \\
+ \text { classifier CNN }\end{array}$ & $\begin{array}{c}\text { Peringkat } 4 \\
\text { dalam SemEval } \\
2017 \\
\text { RumourEval } \\
8 \mathrm{~A}, \text { akurasi } \\
74,9 \% \\
\end{array}$ \\
\hline $\begin{array}{c}\text { Stance } \\
\text { Detection }\end{array}$ & $\begin{array}{c}\text { Shalini, } \\
2019\end{array}$ & $\begin{array}{c}\text { GloVe / W2V + } \\
\text { classifier BoT / } \\
\text { CNN / Bi-LSTM }\end{array}$ & $\begin{array}{c}\text { Bi-LSTM + } \\
\text { BoT emb } \\
\text { memberi } \\
\text { performa } \\
\text { tertinggi } \\
\end{array}$ \\
\hline $\begin{array}{c}\text { Stance } \\
\text { Classification }\end{array}$ & $\begin{array}{c}\text { Jannati, } \\
2019\end{array}$ & $\begin{array}{c}\text { Pemodelan } \\
\text { kalimat rata-rata } \\
\mathrm{W} 2 \mathrm{~V}+\mathrm{SVM}\end{array}$ & $\begin{array}{c}\text { F1 macro } \\
63,54 \%\end{array}$ \\
\hline $\begin{array}{c}\text { Stance } \\
\text { Classification }\end{array}$ & $\begin{array}{l}\text { Setiawan, } \\
2020\end{array}$ & $\begin{array}{c}\text { Pemodelan } \\
\text { kalimat rata-rata } \\
\text { W2V / LSTM } \\
\text { W2V + classifier } \\
\text { LSTM }\end{array}$ & $\begin{array}{l}\text { Pendekatan full } \\
\text { LSTM } \\
\text { memberi } F 1 \\
\text { macro tertinggi }\end{array}$ \\
\hline
\end{tabular}

Pada penelitian Chen [21], tweet yang dikumpulkan berhasil diklasifikasi dengan akurasi tertinggi dengan menambahkan data media sosial pada input dengan classifier CNN. Sementara itu, penelitian Kochkina [22] melakukan stance classification pada tweet dengan menghitung jumlah kata negatif pada tweet dan pemodelan kalimat dengan pendekatan rata-rata. Word embedding yang digunakan adalah model Word2 $\mathrm{Vec}$ pre-trained dengan Google News dataset. Classifier yang digunakan adalah branch-LSTM. Pendekatan ini memenangkan kompetisi RumourEval dengan akurasi $78,4 \%$.

Pendekatan yang mirip untuk mengklasifikasi stance di media sosial juga dilakukan oleh Lozano [19]. Namun, berbeda dengan Kochkina, Lozano menggunakan classifier CNN. Pendekatan ini memperoleh peringkat keempat dengan akurasi 74,9\%. Lozano berargumen CNN memberikan hasil yang akurat pada jumlah data yang kecil tapi juga berisiko overfitting secara cepat.

Sementara itu, Shalini [23] mendapat performa model tertinggi dengan Bi-LSTM dan Bag-of-Tricks embedding dengan Fl score sebesar 79,84\%. Model digunakan untuk mendeteksi stance suatu tweet apakah mendukung atau menolak suatu topik.

Dalam konteks bahasa Indonesia, penelitian yang paling dekat yang juga melakukan stance classification antara dua kalimat judul adalah penelitian Setiawan [16]. Penelitian tersebut menunjukkan stance classification dapat dilakukan dengan pemodelan kalimat dengan LSTM dan diproses ke classifier LSTM dengan F1 macro 71\%. Dalam penelitian tersebut dilakukan pula uji coba pemodelan kalimat dengan pendekatan rata-rata dan classifier LSTM yang menghasilkan $F 1$ macro sebesar $60,66 \%$.

Penulis memosisikan penelitian ini sebagai pengembangan penelitian stance classification berbahasa Indonesia, terutama dari penelitian [16]. Pengembangan ini dilakukan dengan mengubah word embedding menjadi fastText dan menggabungkan model dan fitur-fitur dari penelitian Setiawan [16] dengan pendekatan kalimat pada penelitian Kochkina [22] yang mampu menghasilkan akurasi lebih tinggi. Mengingat penelitian ini meneliti post media sosial, maka diambil juga aspek pengambilan data post seperti jumlah like dan comment seperti pada penelitian [21] dan [19].

\section{A. Stance Classification}

Penelitian stance pada awalnya banyak dilakukan pada bidang-bidang dilluar topik penyebaran hoax, seperti debat kongres [24] dan forum debat online [25]. Namun, pada tahun 2017, diperkenalkan kompetisi Fake News Challenge untuk mengidentifikasi hoax. Fokus dari kompetisi tersebut adalah mencari stance isi berita dengan judul dari artikel berita tersebut. Pada Fake News Challenge, pendekatan yang memiliki akurasi tertinggi adalah pendekatan multilayer perceptrons [26] dan CNN dengan decision tree. Di Indonesia, salah satu penelitian terbaru mengenai stance classification adalah analisis pendapat terhadap berita kesehatan [16]. Dalam paper tersebut, LSTM digunakan untuk mencari vektor kalimat dan sebagai classifier stance.

Penelitian ini dirancang sebagai pengembangan dari penelitian analisis pendapat berita kesehatan dalam konteks media sosial. Penelitian ini juga mengeksplorasi model pembentukan vektor kalimat pendekatan sederhana rata-rata dengan classifier berbasis deep learning. Metode deep learning yang dipilih adalah CNN, LSTM, dan Bi-LSTM.

\section{B. NLP dengan CNN}

Penggunaan Convolutional Neural Network (CNN) untuk penelitian NLP dilakukan pertama kali di tahun 2011 [12]. Konsep CNN dengan lapis max-pooling dikembangkan dengan membuat dua kelompok vektor kata dimana setiap kelompok dianggap sebagai channel. Dengan backpropagation hanya pada satu channel, model dapat melatih satu kelompok vektor sesuai penugasan yang ada. Hal ini juga membuat kelompok vektor yang lain statis [13]. Aplikasi CNN untuk stance classification sendiri dapat 
digabung dengan automatic rule mining, hand written rules, dan voting [19]. Untuk konteks media sosial, penggabungan tersebut adalah model CNN dengan informasi user dan post [21].

\section{NLP dengan LSTM}

LSTM sendiri merupakan pengembangan dari RNN sederhana. Bedanya, LSTM memiliki forget gate yang Dalam penugasan stance, LSTM dapat mengatasi permasalahan kalimat panjang yang dihadapi oleh CNN. Pada penelitian Hanselowski [27], model baru dengan penambahan stacked LSTM mampu menghasilkan peningkatan akurasi klasifikasi Fake News Challenge.

\section{NLP dengan Bi-LSTM}

Bi-LSTM telah diaplikasikan dalam stance detection seperti pada SemEval 2016 Task 6 dalam konteks Twitter [28]. Pada penelitian Habernalt [29], bidirectional LSTM terbukti lebih akurat dalam membandingkan makna kalimat satu dengan yang lain terhadap sebuah topik. Mrowca [30] menggunakan Bi-LSTM untuk mengambil informasi fitur kalimat judul berita dan teks dari isi berita tersebut dalam Fake News Challenge. Klasifikasi sendiri dilakukan dengan menggabungkan output dari Bi-LSTM dan vektor fitur.

\section{E. Word dan Sentence Embedding}

Word embedding berbasis neural network dimulai pada tahun 2003 dengan feedforward neural network model pada penelitian Bengio [31]. Untuk mengurangi kompleksitas komputasional, Mikolov memperkenalkan Word2Vec yang juga mampu mengekstrak similaritas antar vektor kata dengan cosine similarity [11].

FastText [17] adalah hasil pengembangan dari Word2Vec. Berbeda dari Word2Vec, fastText tidak memakai hanya satu kata secara utuh untuk diproses, tapi fastText menggunakan n-gram. Contoh aplikasi n-gram pada kata "program" dengan trigram $(n=3)$ berupa "pro", "rog", "ogr", "gra", "ram". Kelebihan fastText adalah waktu proses yang relatif cepat. FastText terbukti efektif dalam klasifikasi teks seperti sentiment analysis [32]. Kombinasi CNN dan fastText juga terbukti lebih akurat dalam klasifikasi sentimen dibandingkan menggunakan Word2Vec [33].

Pada bidang sentence embedding, Kiros memperkenalkan Skip-thought vector, dimana sebuah kalimat akan ditebak berdasarkan kalimat disekitarnya, seperti konsep Skip-gram [34]. Permasalahan durasi pelatihan yang lama dijawab dengan Quick-thought vectors [35]. Penurunan waktu pelatihan ini dikarenakan penentuan kalimat berikutnya yang menggunakan classifier, bukan encoder-decoder RNN seperti Skip-thought.

Namun, pembentukan vektor kalimat dengan metode sederhana seperti rata-rata dari word embedding juga dapat menghasilkan performa yang bagus [36]. Dalam penelitian Wieting [37], model paragram-phrase yang dibentuk dengan rata-rata dari vektor kata mampu mengalahkan model LSTM dalam tugas pengenalan similaritas teks.

\section{Metodologi Penelitian}

Proses penelitian ini dimulai dari pengumpulan data, pembentukan vektor kata dan kalimat, pengambilan fitur kalimat dan post, dan deep learning classifier untuk klasifikasi stance. Gambar 1 menjabarkan alur sistem penelitian ini.

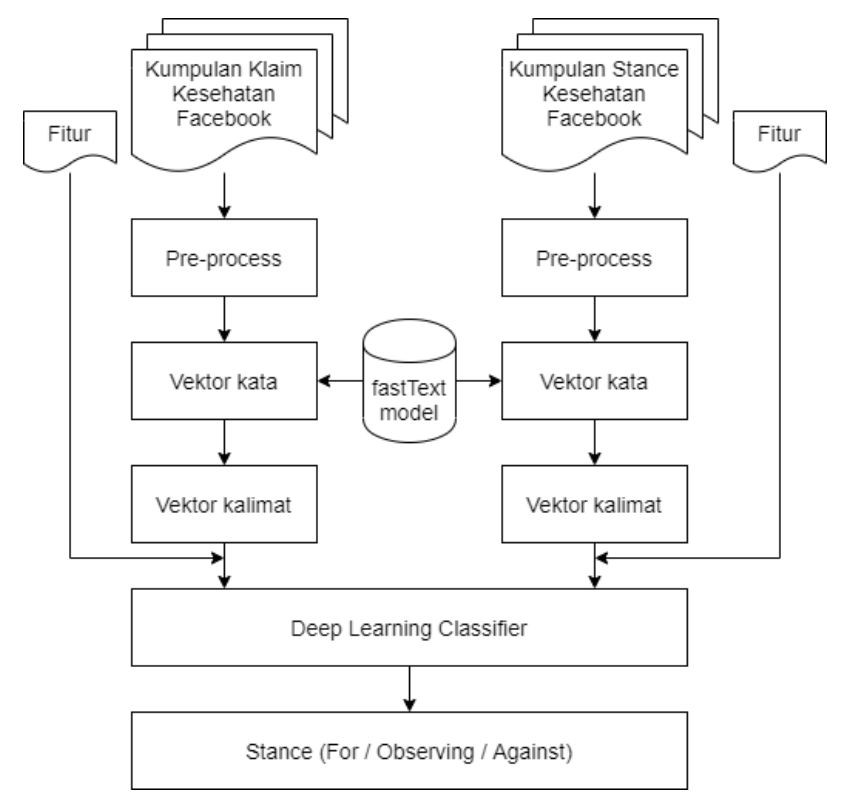

Gambar 1. Alur Sistem Penelitian

Penelitian ini sendiri akan dibatasi dengan hanya mengambil data dari post Facebook bertopik kesehatan. Peneliti hanya akan mengambil judul artikel yang dishare, judul pada gambar di post, atau teks judul pada post seperti pada Gambar 2. Panjang dari teks tersebut adalah satu kalimat atau lebih. Klasifikasi akan dilakukan hanya dengan CNN, LSTM, dan Bi-LSTM. Kelas klasifikasi sendiri terdiri dari tiga stance, yaitu: for, observing dan against.
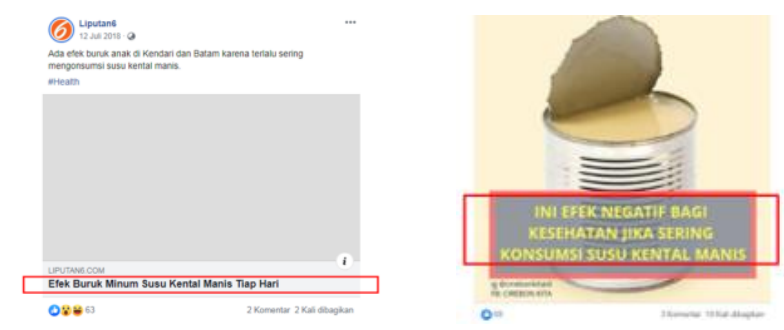

Gambar 2. Contoh Pengambilan Teks dan Post (Kotak Merah)

\section{A. Dataset}

Kalimat klaim maupun stance didasarkan pada dataset Indonesian News Stance Dataset [16]. Dalam penelitian ini, peneliti mencari post klaim dan post reaksi di Facebook berdasar kalimat klaim dan kalimat-kalimat reaksinya. Saat tidak ditemukan judul post Facebook yang berisi teks-teks tersebut, data yang diambil berupa judul-judul post Facebook dengan topik lain yang masih termasuk dalam bidang kesehatan. Hal ini mengakibatkan perubahan 350 kalimat klaim (70\%) dari total 500 kalimat klaim di Indonesian News Dataset. Peneliti juga menambahkan informasi jumlah like dan comment pada setiap post.

Pengambilan data dilakukan secara manual di Facebook. Data yang dicari adalah judul artikel/judul gambar/judul post Facebook bersifat klaim, tanggal post klaim, URL post klaim, jumlah like pada post, dan jumlah comment. Data 
yang dicari pada post stance sama dengan post klaim dengan penambahan data stance. Penentuan klaim dan stance dilakukan berdasar opini pengambil data. Data disimpan dalam bentuk file .CSV dan dipisah menjadi kolom-kolom tersendiri. Proses pengambilan data ini dapat diilustrasikan sebagai flowchart dalam gambar 3 berikut ini.

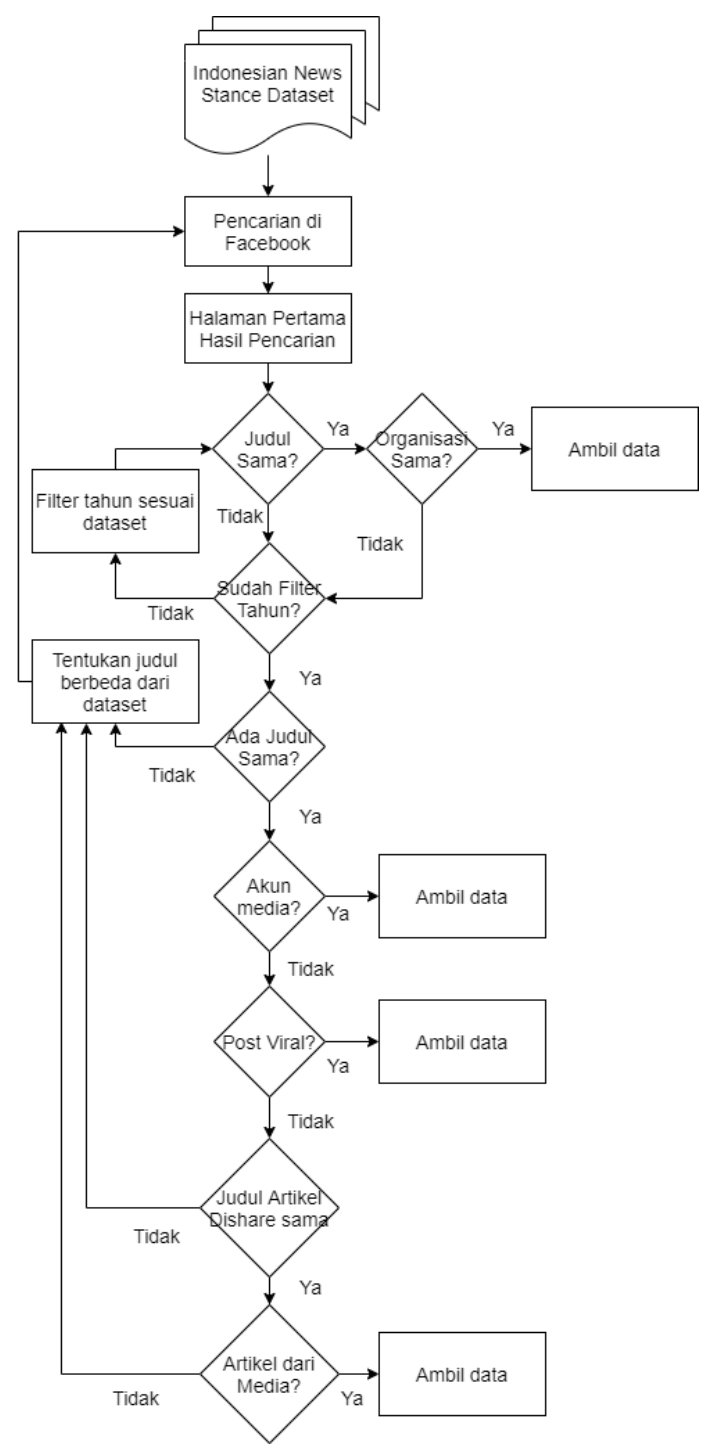

Gambar 3. Alur Sistem Pemilihan Post untuk Dataset

Proses pengambilan data post klaim dan post terkait beserta stance diawali dengan pencarian di kotak pencarian Facebook. Query pencarian adalah kalimat judul pada Indonesian News Stance Dataset dengan nama organisasi pembuat artikel tersebut. Contoh, kalimat pencarian "liputan6 Efek Buruk Minum Susu Kental Manis Tiap Hari" berasal dari artikel liputan6 yang berjudul "Efek Buruk Minum Susu Kental Manis Tiap Hari”. Bila ditemukan post berjudul artikel tersebut dari akun organisasi yang sama, maka akan diketik data yang dibutuhkan ke dalam file .CSV.

Bila tidak ditemukan post dengan kalimat tersebut pada halaman hasil pertama, pengambil data akan melakukan ulang pencarian dengan pemilihan filter tahun post sesuai dengan data tahun post pada Indonesian News Stance Dataset. Bila masih tidak ditemukan post dengan judul dan organisasi yang sama, maka dapat dilakukan satu dari dua solusi berikut: dilakukan pengambilan post dengan judul yang sama tapi dengan organisasi atau user yang berbeda, atau pengambil data mencari topik kesehatan baru di kotak pencarian di Facebook.

Pengambil data memilih post hasil pencarian bertopik baru dengan prioritas utama post milik akun organisasi media, mulai dari media berskala nasional, hingga daerah. Hal ini dilakukan untuk memperbesar kemungkinan mendapat post dengan reaksi besar. Prioritas kedua adalah post perorangan yang viral, terlihat dari jumlah like yang bisa mencapai satu juta lebih. Prioritas ketiga adalah post berjudul sama dengan kalimat topik pencarian milik akun perorangan. Berikut ini, pada Tabel II, adalah salah satu contoh pasangan judul klaim dan judul berkaitan yang didapat.

TABEL II

CONTOH KLAIM DAN STANCE

\begin{tabular}{|c|c|c|}
\hline $\begin{array}{l}\text { Judul } \\
\text { Klaim }\end{array}$ & Judul Reaksi & Stance \\
\hline \multirow{6}{*}{$\begin{array}{l}\text { Dua Studi } \\
\text { Ini } \\
\text { Buktikan } \\
\text { Manfaat } \\
\text { Rokok } \\
\text { Elektrik } \\
\text { untuk } \\
\text { Berhenti } \\
\text { Merokok }\end{array}$} & $\begin{array}{c}\text { Manfaat Vaping untuk Kesehatan yang } \\
\text { Perlu Anda Ketahui }\end{array}$ & for \\
\hline & $\begin{array}{l}\text { Riset tiga tahun dari Italia pastikan rokok } \\
\text { elektrik tidak bahaya }\end{array}$ & for \\
\hline & $\begin{array}{c}\text { Vape Alias Rokok Elektrik, Apakah } \\
\text { Bahaya Bagi Tubuh? }\end{array}$ & observing \\
\hline & $\begin{array}{l}\text { Kelebihan dan Bahaya Rokok Elektrik } \\
\text { untuk Kamu yang Masih Mahasiswa! }\end{array}$ & observing \\
\hline & $\begin{array}{c}5 \text { Bahaya yang Mengintai di Balik } \\
\text { Nikmatnya Vape }\end{array}$ & against \\
\hline & $\begin{array}{l}\text { Bahaya dan Efek Samping Vape yang } \\
\text { Negatif Mengintai Para Penggunanya }\end{array}$ & against \\
\hline
\end{tabular}

Secara total, peneliti mendapat 3.500 judul post Facebook bertopik kesehatan yang berbahasa Indonesia. Dari data tersebut, 500 kalimat adalah kalimat klaim. Setiap kalimat klaim memiliki beberapa kalimat reaksi, yaitu: dua kalimat stance for (setuju dengan kalimat klaim), dua kalimat stance observing (netral terhadap kalimat klaim), dan dua kalimat against (bertentangan dengan kalimat klaim) yang juga diambil dan diberi label secara manual. Distribusi data dapat dilihat pada Tabel III.

TABEL III

Distribusi Data DALAM DATASET PENELITIAN

\begin{tabular}{|l|l|}
\hline Jenis Data & Jumlah \\
\hline Klaim & 500 \\
\hline For & 1000 \\
\hline Observing & 1000 \\
\hline Against & 1000 \\
\hline Total & 3500 \\
\hline
\end{tabular}

\section{B. Pembentukan Vektor Kata dan Kalimat}

Embedding kata dan kalimat dilakukan untuk memetakan nilai vektor berdasarkan embedding fastText. Sebelum dipetakan, setiap kalimat akan melalui pre-processing terlebih dahulu.

Pre-processing dimulai dengan case folding, tokenisasi dengan word_tokenize dari nltk, dan filtering untuk membuang kata-kata tidak penting seperti "yang", "untuk", "pada", "ke" dan lain-lain berdasar stopwords dari Tala [38]. Karakter spesial juga akan dihapus kecuali tanda tanya, tanda hubung, dan 0-9.

Penelitian ini menggunakan pre-trained fastText dengan dimensi 300. Dalam setiap kalimat, token kata akan diubah 
menjadi vektor berdimensi 300 berdasar vektor pre-trained fastText cc.id.300.bin.

Semua kalimat akan melalui proses padding dengan vektor 0 sehingga semua kalimat akan memiliki besar matriks yang sama dengan kalimat dengan jumlah kata terbanyak. Setelah itu, vektor kalimat klaim dibentuk dengan menghitung rata-rata dari setiap vektor kata dalam kalimat.

\section{Pengambilan Fitur Kalimat dan Post}

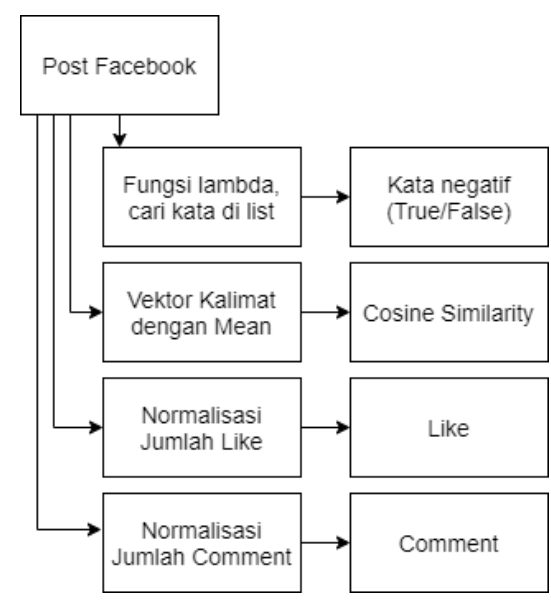

Gambar 4. Pembentukan Fitur

Pembentukan fitur secara garis besar dapat dilihat pada gambar 4. Pengambilan fitur kata negatif dan cosine similarity dilakukan pada setiap kalimat klaim dan stance. Pada aspek fitur kata negatif, peneliti menambah data Boolean mengenai ada atau tidaknya kata-kata negatif dalam kalimat klaim dan stance. Kata-kata negatif tersebut adalah 'tidak', 'bukan', 'jangan', 'tak', 'belum', 'mitos', 'hoaks', dan 'hoax'. Penentuan kata-kata negatif berdasar pada penelitian sebelumnya [16], dimana setiap vektor kalimat akan diperpanjang dengan menambahkan nilai Boolean tadi.

Cosine similarity digunakan untuk mengetahui kemiripan vektor dengan mengukur sudut kosinus dari kedua vektor tersebut. Cosine similarity akan menghasilkan nilai 0 hingga 1, dimana hasil yang semakin dekat dengan 1 menunjukkan dua vektor yang memiliki banyak kemiripan. Terlihat pada rumus (1), cosine similarity memiliki dua komponen yang dalam penelitian ini adalah kalimat klaim dan kalimat stance.

$$
\text { cosine similarity }=\frac{\sum_{i=1}^{n} A_{i} B_{i}}{\sqrt{\sum_{i=1}^{n} A_{i}^{2}} \sqrt{\sum_{i=1}^{n} B_{i}^{2}}}
$$

Pada aspek fitur post, peneliti mengambil informasi jumlah like dan jumlah komentar setiap post. Setelah dinormalisasi, jumlah like dan jumlah komentar akan ditambahkan ke vektor kalimat.

\section{Fitur Kalimat dan Fitur Media Sosial}

Dalam penelitian stance classification, Chen [21] memanfaatkan berbagai metadata untuk membantu mengetahui stance dari tweet. Informasi user adalah data yang paling penting, diikuti oleh informasi topik dan komentar. Pada penelitian Lozano [19], metadata yang diambil adalah terbagi menjadi empat kriteria, yaitu: 1) jumlah tanda baca dan kata negasi pada tweet, 2) jumlah status, follower, dan tweet favorit user, 3) status verifikasi user, 4) apakah tweet termasuk tweet reply dan seberapa panjang thread tweet tersebut. Selain itu, Lozano juga menerapkan beberapa aturan dalam proses pelabelan stance pada tweet. Aturan pertama adalah pemberian label deny bila tweet mengandung frasa ' $n o t$ believable'. Aturan kedua adalah pemberian label support bila terdapat URL dan tidak mengandung@-mention.

Pada penelitian ini, dalam konteks Facebook, peneliti mengambil metadata ada atau tidaknya tanda tanya, jumlah like, dan jumlah comment. Peneliti juga menentukan beberapa kata negatif yang diasosiasikan dengan stance against.

\section{E. Parameter Penting dalam Classifier}

Beberapa penelitian tentang parameter penting pada $\mathrm{CNN}$ [39] dan LSTM [36]. Pada CNN, ada beberapa parameter yang harus diperhatikan, yaitu: 1) penggunaan representasi vektor kata, 2) filter region size yang perlu disesuaikan terhadap penugasannya, 3) peningkatan nilai feature maps akan meningkatkan waktu pelatihan model, 4) 1-max pooling memberikan performa terbaik, dan 5) regularisasi tidak berdampak signifikan terhadap performa.

Pada LSTM, akurasi LSTM sangat dipengaruhi oleh jumlah token, pengaturan dimensi disesuaikan dengan tujuan, dan penambahan hidden unit yang terkadang justru memperburuk akurasi.

\section{F. Deep Learning Classifier}

\section{- Model Classifier CNN}

Pemrosesan vektor dengan CNN pada algoritme 7.1 dilakukan dengan beberapa tahap. Pertama, vektor kalimat klaim akan diproses dengan filter dari CNN. Ukuran dari filter ini ditentukan pada saat pembuatan lapis convolutional 1D. Dalam kasus teks, nilai kernel menentukan jumlah baris filter, dan nilai filters menjadi panjang filter. Penelitian ini menggunakan kernel_size $=1$ sehingga filter memproses per 1 kalimat. Setelah menentukan ukuran filter, perhitungan jumlah dari produk per elemen. Dari hasil tersebut, diambil nilai maksimal dengan 1-max pooling. Program kemudian mengubah shape dengan flatten sehingga matriks hasil pooling menjadi satu vektor. Vektor tersebut kemudian diproses dengan lapis dense untuk mendapat dimensi yang sesuai dengan panjang one-hot label dan softmax untuk mencari probabilitas stance tertinggi pada matriks pasangan vektor tadi.

Parameter classifier CNN yang digunakan adalah sebagai berikut: 1) lapis convolutional $1 D$ dengan filters $=304$, kernel_size=1, aktivasi ReLU, 2) lapis dropout sebesar 0,5 , 3) lapis max pooling $1 D$ dengan pool size sebesar satu, 4) lapis flatten, 5) lapis dense dengan output 50 unit dan aktivasi ReLU, dan 6) lapis dense output 3 unit dengan softmax untuk mengetahui probabilitas stance. Model dibentuk dengan optimizer Adam dengan learning rate sebesar 0,001 .

\section{- Model Classifier LSTM}

Pemrosesan vektor dengan LSTM dilakukan dengan menginput vektor gabungan klaim ke dalam lapis LSTM ke 
dalam input gate. LSTM memiliki sistem gate untuk menangani masalah vanishing gradient. Sistem proses LSTM terdiri dari lima modul, yaitu: input gate, new memory cell, forget gate, final memory generation, dan output gate. Dalam input gate, program membuat memory baru dengan menghitung vektor input tadi dengan activation function dan melihat hidden state dari LSTM sebelumnya, yang saat ini masih tidak ada. Sementara itu, forget gate menilai apakah cell sebelumnya diperlukan untuk perhitungan cell sekarang dengan melihat vektor input dan hidden state sebelumnya. Nilai dari kedua proses sebelumnya kemudian dijumlahkan dalam final memory cell (Ct). Setelah itu, output gate menentukan seberapa besar memory $\mathrm{Ct}$ yang perlu digunakan dalam langkah waktu saat ini. Nilai output dari cell ini adalah hasil perkalian dari output gate dan $\mathrm{Ct}$ yang telah melalui lapis activation function. Proses ini diulang Kembali untuk input vektor gabungan judul yang berkaitan dengan klaim pada langkah waktu berikutnya dengan hidden state dari proses dengan vektor gabungan klaim tadi. Output dari cell ini yang akan diproses ke lapis dense dan lapis output softmax untuk mendapat stance.

\section{- Model Classifier Bi-LSTM}

Bi-LSTM memiliki alur yang mirip dengan LSTM, hanya bedanya terdapat satu rangkaian LSTM tambahan yang menghitung dari input paling terkahir hingga input paling awal (backward LSTM). Sehingga terdapat dua rangkaian LSTM, forward LSTM dan backward LSTM. Algoritme classifier Bi-LSTM dapat dilihat pada algoritme 7.3. Langkah pertama dari algoritme, vektor gabungan klaim akan diinputkan terlebih dahulu ke dalam lapis forward LSTM. Langkah-langkah ini sama dengan langkah 01-10 pada algoritme 7.2. Program juga akan menjalankan backward LSTM. Input langkah waktu pertama adalah vektor terakhir, yaitu vektor gabungan judul berkaitan. Vektor ini diproses Dalam input gate, program membuat memory baru dengan menghitung vektor input tadi dengan activation function dan melihat hidden state dari LSTM sebelumnya, yang saat ini masih tidak ada. Sementara itu, forget gate menilai apakah cell sebelumnya diperlukan untuk perhitungan cell sekarang dengan melihat vektor input dan hidden state sebelumnya. Nilai dari kedua proses sebelumnya kemudian dijumlahkan dalam final memory cell (Ct). Setelah itu, output gate menentukan seberapa besar memory $\mathrm{Ct}$ yang perlu digunakan dalam langkah waktu saat ini. Nilai output dari cell ini adalah hasil perkalian dari output gate dan $\mathrm{Ct}$ yang telah melalui lapis activation function. Proses ini diulang untuk input vektor gabungan klaim dengan hidden state dari proses dengan vektor gabungan judul berkaitan tadi. Output dari cell backward LSTM ini yang akan diproses ke lapis dense dan lapis output softmax untuk mendapat stance, bersamaan dengan output dari cell forward LSTM.

Pada classifier LSTM dan Bi-LSTM, pengaturan parameter yang digunakan adalah: 1) lapis LSTM/Bi-LSTM dengan dua langkah waktu, input dengan dimensi 304 dan recurrent dropout sebesar 0.5 , dan output 200 unit 2) lapis dense dengan aktivasi ReLU dan output 100 unit, dan 3) lapis dense output tiga unit dengan aktivasi softmax. Model LSTM dan Bi-LSTM ini juga dibentuk dengan optimizer
Adam dengan learning rate default sebesar 0,001.

\section{G. Sistem Evaluasi Performa}

Performa model dilihat berdasarkan F1 score setiap kelas stance dan F1 macro. F1 score diperoleh dengan menghitung harmonic mean dari precision dan recall, seperti pada rumus 2. Nilai $F 1$ score memiliki rentang 0 hingga 1 dimana nilai 1 menunjukkan akurasi maksimal.

$$
F 1=2 \times \frac{\text { Precision } * \text { Recall }}{\text { Precision }+ \text { Recall }}
$$

Precision, dalam konteks klasifikasi, pada rumus 8.2, adalah nilai dari pembagian true positive (tp) dengan jumlah dari true positive (tp) dan false positive (fp). Rumus 3 berikut menunjukkan rumus precision.

$$
\text { Precision }=\frac{t p}{t p+f p}
$$

Sementara itu, recall, dalam konteks klasifikasi, adalah nilai dari pembagian true positive (tp) dengan jumlah dari true positive (tp) dan false negative (fn). Rumus 4 berikut menunjukkan rumus recall.

$$
\text { Recall }=\frac{t p}{t p+f n}
$$

Istilah true positive (tp), true negative (tn), false positive (fp), dan false negative (fn) dapat dijabarkan sebagai berikut.

Istilah true dan false dalam rumus-rumus tersebut mengacu pada kebenaran sebuah prediksi. Sebagai contoh, classifier memprediksi sebuah judul memiliki stance for terhadap sebuah klaim. Bila label judul tersebut (data Y) pada dataset adalah for, maka hasil prediksi bersifat true. Bila data Y pada dataset adalah observing atau against, maka hasil prediksi bersifat false.

Sementara itu, istilah positive dan negative mengacu pada hasil prediksi yang diharapkan. Contoh, saat menghitung precision stance observing, maka semua prediksi yang menghasilkan stance observing masuk dalam kategori positive dan sisanya, prediksi dengan hasil stance for dan observing, sebagai anggota kategori negative.

Penelitian ini menggunakan fungsi classification_report dari sklearn.metrics untuk mendapat tabel mengenai performa model. Aspek-aspek yang terdapat dalam tabel tersebut adalah nilai precision, nilai recall, F1 score, dan macro average F1 score.

\section{ANALISIS DAN PEMBAHASAN}

Untuk mendapatkan arsitektur yang efektif dalam stance classification, peneliti menguji coba model dengan beberapa parameter dan metode yang berbeda. Dalam eksperimen, data uji coba adalah $20 \%$ dari jumlah data yang ada. Peneliti menggunakan macro-average F1-score untuk mengetahui akurasi prediksi semua label dan F1-score untuk mengetahui akurasi prediksi pada setiap label.

Dalam setiap uji coba, program akan menghitung $F 1$ score dan F1 macro dari sepuluh seed dari model, sehingga terdapat 10 classification report dalam setiap uji coba. Hasil 
uji coba adalah rata-rata $F 1$ score dan $F 1$ macro dari sepuluh classification report tersebut.

Aspek-aspek yang diuji cobakan dalam eksperimen ini, yaitu: 1) jenis word embedding, 2) pengaruh hasil pelatihan word embedding, 3) jenis classifier, 4) fitur kalimat dan media sosial, 5) dropout dan jenis activation, dan 6) hidden units.

\section{A. Jenis Word Embedding}

Pada uji coba pengaruh jenis word embedding, peneliti membandingkan performa antara Word2Vec menggunakan vektor pre-trained Kyubyong yang berdimensi 300 (https://github.com/Kyubyong/wordvectors) dan fastText cc.id.300.bin yang juga berdimensi 300. Penentuan Word2Vec sebagai perbandingan mengacu pada penelitian sebelumnya yang menggunakan Word2Vec untuk mengklasifikasi pendapat di Twitter dengan metode pemodelan kalimat yang sama dengan penelitian ini [22].

Pada Tabel IV terlihat bahwa ada perbedaan akurasi sebesar $1,1 \%$ antara rata-rata $F 1$ macro model dengan Word2Vec $(52,7 \%)$ terhadap model dengan fastText $(53,8 \%)$. Penggunaan Word2Vec paling akurat dengan LSTM hanya mencapai $55 \%$ dan penggunaan fastText paling akurat diperoleh dengan $\mathrm{CNN}$ dengan $F 1$ macro $55,4 \%$.

TABEL IV

HASIL UJI COBA JENIS WORD EMBEDDING

\begin{tabular}{|l|l|l|l|l|}
\hline Pendekatan & F1 for & $\begin{array}{l}\text { F1 } \\
\text { observing }\end{array}$ & $\begin{array}{l}\text { F1 } \\
\text { against }\end{array}$ & $\begin{array}{l}\text { F1 } \\
\text { Macro }\end{array}$ \\
\hline $\begin{array}{l}\text { Word2Vec + } \\
\text { CNN }\end{array}$ & 0.454 & 0.654 & 0.488 & 0.532 \\
\hline $\begin{array}{l}\text { Word2Vec + } \\
\text { LSTM }\end{array}$ & 0.503 & 0.659 & 0.488 & 0.550 \\
\hline $\begin{array}{l}\text { Word2Vec + Bi- } \\
\text { LSTM }\end{array}$ & 0.453 & 0.624 & 0.424 & 0.500 \\
\hline Rata-rata & $\mathbf{0 . 4 7 0}$ & $\mathbf{0 . 6 4 6}$ & $\mathbf{0 . 4 6 7}$ & $\mathbf{0 . 5 2 7}$ \\
\hline fastText + CNN & $\mathbf{0 . 4 9 5}$ & $\mathbf{0 . 8 2 4}$ & 0.345 & $\mathbf{0 . 5 5 4}$ \\
\hline fastText + LSTM & 0.492 & 0.801 & 0.294 & 0.529 \\
\hline $\begin{array}{l}\text { fastText + Bi- } \\
\text { LSTM }\end{array}$ & 0.441 & 0.817 & $\mathbf{0 . 3 9 1}$ & 0.530 \\
\hline Rata-rata & $\mathbf{0 . 4 7 6}$ & $\mathbf{0 . 8 1 4}$ & $\mathbf{0 . 3 4 3}$ & $\mathbf{0 . 5 3 8}$ \\
\hline
\end{tabular}

\section{B. Pemilihan Hasil Pelatihan Word Embedding}

Terlilhat pada Tabel $\mathrm{V}$ bahwa penggunaan vektor pretrained harus disesuaikan dengan banyaknya fitur yang dipakai dalam penelitian. Bila hanya menggunakan vektor kalimat sebagai input, maka wiki.id.bin akan lebih akurat $(54,7 \%)$ dibandingkan dengan cc.id.300.bin (53,8\%). Namun, bila ada penambahan vektor fitur, seperti informasi kata negatif, cosine similarity, jumlah like dan comment, cc.id.300.bin akan menghasilkan model yang lebih akurat dengan F1 macro sebesar $60 \%$ dibandingkan dengan $50 \%$ dengan wiki.id.bin.

TABEL V

HASIL UJI COBA WORD EMBEDDING FASTTEXT PRE-TRAINED

\begin{tabular}{|l|l|l|l|l|}
\hline $\begin{array}{l}\text { Vektor Pre- } \\
\text { Trained }\end{array}$ & $\begin{array}{l}F 1 \\
\text { for }\end{array}$ & $\begin{array}{l}\text { F1 } \\
\text { observing }\end{array}$ & $\begin{array}{l}\text { F1 } \\
\text { against }\end{array}$ & F1 Macro \\
\hline cc.id.300.bin & 0,476 & 0,814 & 0,343 & 0,538 \\
\hline Tanpa Fitur & 0,54 & 0,789 & 0,461 & $\mathbf{0 , 6 0 0}$ \\
\hline Dengan Fitur & 0,549 & \\
\hline wiki.id.bin \\
\hline Tanpa Fitur & 0,484 & 0,823 & 0,337 & $\mathbf{0 , 5 4 7}$ \\
\hline Dengan Fitur & 0,536 & 0,628 & 0,406 & 0,500 \\
\hline
\end{tabular}

\section{Jenis Classifier}

Dalam Tabel VI, terlihat hasil dari uji coba bila input hanya menggunakan vektor kalimat tanpa penambahan fitur. Ditemukan bahwa metode classifier $\mathrm{CNN}$ justru memberi F1 macro tertinggi dengan cc.id.bin $(55,4 \%)$. Hasil yang hampir sama juga didapat dengan wiki.id.bin.

TABEL VI

Hasil Uji Coba Metode Classifier CnN, Lstm, DAN Bi-Lstm, Dengan FASTTEXT CC.ID.300.BIN DAN WIKI.ID.BIN

\begin{tabular}{|l|l|l|l|l|}
\hline Classifier & F1 for & $\begin{array}{l}\text { F1 } \\
\text { observing }\end{array}$ & $\begin{array}{l}\text { F1 } \\
\text { against }\end{array}$ & $\begin{array}{l}\text { F1 } \\
\text { Macro }\end{array}$ \\
\hline \multicolumn{5}{|l|}{ cc.id.300.bin } \\
\hline CNN & $\mathbf{0 . 4 9 5}$ & $\mathbf{0 . 8 2 4}$ & 0.345 & $\mathbf{0 . 5 5 4}$ \\
\hline LSTM & 0.492 & 0.801 & 0.294 & 0.529 \\
\hline Bi-LSTM & 0.441 & 0.817 & $\mathbf{0 . 3 9 1}$ & 0.530 \\
\hline \multicolumn{5}{|l|}{ wiki.id.bin } \\
\hline CNN & $\mathbf{0 . 5 1 2}$ & 0.807 & 0.345 & $\mathbf{0 . 5 5 3}$ \\
\hline LSTM & 0.445 & 0.827 & $\mathbf{0 . 3 5 0}$ & 0.540 \\
\hline Bi-LSTM & 0.496 & $\mathbf{0 . 8 3 4}$ & 0.315 & 0.547 \\
\hline
\end{tabular}

\section{Fitur Kalimat dan Post}

Pada Tabel VII tampak bahwa adanya informasi keberadaan kata negatif dan cosine similarity mengakibatkan adanya perbaikan performa yang cukup besar. Akurasi Bi-LSTM meningkat sebesar 9,4\% menjadi $62,4 \%$ dari $53 \%$ tanpa penambahan vektor fitur. Akurasi masing-masing aspek uji coba dengan CNN juga memberikan hasil yang tertinggi, kecuali pada fitur kata negatif saja dan fitur cosine similarity saja. Nilai F1 Macro tertinggi didapat oleh CNN dengan 62,9\%. Model Bi-LSTM juga memperoleh hasil yang cukup serupa dengan $62,4 \%$. Nilai F1 Macro dari pemodelan kalimat dengan rata-rata dan classifier CNN dan Bi-LSTM juga memberikan akurasi yang lebih tinggi daripada hasil uji coba sebesar 60,66\% pada penelitian sebelumnya [16]. Akan tetapi, penambahan fitur likes dan comment justru memperburuk akurasi dari setiap classifier. CNN mengalami penurunan menjadi $60 \%$ dan Bi-LSTM menjadi 61,3\%.

TABEL VII

HASil Uji COBA VeKTOR KaLIMAT DAN FitUR KALIMAT DAN POST

\begin{tabular}{|l|l|l|l|l|}
\hline Classifier & F1 for & $\begin{array}{l}\text { F1 } \\
\text { observing }\end{array}$ & $\begin{array}{l}\text { F1 } \\
\text { against }\end{array}$ & $\begin{array}{l}\text { F1 } \\
\text { Macro }\end{array}$ \\
\hline Tanpa Vektor Fitur & $\mathbf{0 . 3 4 5}$ & $\mathbf{0 . 5 5 4}$ \\
\hline CNN & $\mathbf{0 . 4 9 5}$ & $\mathbf{0 . 8 2 4}$ & 0.294 & 0.529 \\
\hline LSTM & 0.492 & 0.801 & 0.391 & 0.530 \\
\hline Bi-LSTM & 0.441 & 0.817 & 0.443 & 0.600 \\
\hline Dengan Vektor Fitur Kata Negatif & 0.602 \\
\hline CNN & $\mathbf{0 . 5 7 9}$ & 0.778 & 0.468 & $\mathbf{0 . 6 1 8}$ \\
\hline LSTM & 0.552 & 0.785 & $\mathbf{0 . 5 1 2}$ \\
\hline Bi-LSTM & 0.539 & $\mathbf{0 . 8 0 7}$ & 0.539 \\
\hline Dengan Vektor Fitur Cosine Similarity \\
\hline CNN & 0.440 & 0.745 & $\mathbf{0 . 4 3 2}$ \\
\hline LSTM & $\mathbf{0 . 5 1 3}$ & 0.774 & 0.312 & 0.535 \\
\hline Bi-LSTM & 0.463 & $\mathbf{0 . 7 9 3}$ & 0.381 & $\mathbf{0 . 5 4 7}$ \\
\hline Dengan Vektor Fitur Kata Negatif + Cosine Similarity \\
\hline CNN & $\mathbf{0 . 5 8 8}$ & 0.791 & $\mathbf{0 . 5 1 1}$ & $\mathbf{0 . 6 2 9}$ \\
\hline LSTM & 0.530 & 0.802 & 0.481 & 0.605 \\
\hline Bi-LSTM & 0.543 & $\mathbf{0 . 8 2 2}$ & 0.510 \\
\hline $\begin{array}{l}\text { Dengan Vektor Fitur Kata Negatif + Cosine Similarity + Likes dan } \\
\text { Comment }\end{array}$ & $\mathbf{0 . 5 6 1}$ & $\mathbf{0 . 8 0 2}$ & 0.433 & 0.600 \\
\hline CNN & 0.534 & 0.781 & 0.451 \\
\hline LSTM & 0.553 & 0.785 & $\mathbf{0 . 5 0 0}$ & $\mathbf{0 . 6 1 3}$ \\
\hline Bi-LSTM & \multicolumn{5}{|l|}{} \\
\hline
\end{tabular}




\section{E. Dropout dan Jenis Activation}

Dalam Tabel VIII, terbukti bahwa akurasi tertinggi sebesar $62,9 \%$ dicapai dengan nilai dropout 0,5 dengan activation ReLU. Peningkatan nilai dropout tampak menurunkan akurasi dari semua model, terutama pada model classifier CNN yang hanya menghasilkan F1 macro sebesar $37,6 \%$.

TABEL VIII

HASIL UJI COBA DROPOUT DAN ACTIVATION RELU

\begin{tabular}{|l|l|l|l|l|}
\hline Classifier & F1 for & $\begin{array}{l}\text { F1 } \\
\text { observing }\end{array}$ & $\begin{array}{l}\text { F1 } \\
\text { against }\end{array}$ & $\begin{array}{l}\text { F1 } \\
\text { Macro }\end{array}$ \\
\hline Dropout $\mathbf{0 . 5}+$ ReLU \\
\hline CNN & $\mathbf{0 . 5 8 8}$ & 0.791 & $\mathbf{0 . 5 1 1}$ & $\mathbf{0 . 6 2 9}$ \\
\hline LSTM & 0.530 & 0.802 & 0.481 & 0.605 \\
\hline Bi-LSTM & 0.543 & $\mathbf{0 . 8 2 2}$ & 0.510 & 0.624 \\
\hline Dropout 0.75 + ReLU & $\mathbf{0 . 5 9 1}$ & 0.780 & 0.405 & 0.592 \\
\hline CNN & 0.538 & 0.798 & 0.452 & 0.597 \\
\hline LSTM & 0.506 & $\mathbf{0 . 8 0 8}$ & $\mathbf{0 . 5 1 1}$ & $\mathbf{0 . 6 0 9}$ \\
\hline Bi-LSTM & 0.108 & 0.484 & 0.172 & 0.253 \\
\hline Dropout $0.99+$ ReLU & 0.539 & $\mathbf{0 . 7 9 2}$ & $\mathbf{0 . 3 8 4}$ & 0.572 \\
\hline CNN & $\mathbf{0 . 5 7 2}$ & $\mathbf{0 . 7 9 1}$ & $\mathbf{0 . 3 8 0}$ & $\mathbf{0 . 5 8 2}$ \\
\hline LSTM
\end{tabular}

Terbukti pula bahwa activation function Leaky ReLU hanya mampu meningkatkan efektifitas sebesar 0,4\% pada model LSTM dibandingkan dengan model yang menggunakan ReLU. F1 Macro model justru menurun untuk model lain. F1 Macro CNN turun 1,4\% menjadi $61,5 \%$ dan Bi-LSTM turun $2,8 \%$ menjadi $59,6 \%$. Leaky ReLU sendiri paling akurat apabila digunakan dengan nilai dropout 0,5. Kombinasi ini menghasilkan F1 macro tertinggi pada model classifier CNN sebesar $61,5 \%$ seperti yang tampak pada Tabel IX.

TABEL IX

HASIL UJI COBA DROPOUT DAN ACTIVATION LEAKY RELU

\begin{tabular}{|l|l|l|l|l|}
\hline Classifier & F1 for & $\begin{array}{l}\text { F1 } \\
\text { observing }\end{array}$ & $\begin{array}{l}\text { F1 } \\
\text { against }\end{array}$ & $\begin{array}{l}\text { F1 } \\
\text { Macro }\end{array}$ \\
\hline Dropout $\mathbf{0 . 5}+$ Leaky ReLU \\
\hline CNN & $\mathbf{0 . 5 6 8}$ & 0.780 & $\mathbf{0 . 5 0 4}$ & $\mathbf{0 . 6 1 5}$ \\
\hline LSTM & 0.533 & $\mathbf{0 . 8 0 9}$ & 0.482 & 0.609 \\
\hline Bi-LSTM & 0.519 & 0.778 & 0.495 & 0.596 \\
\hline Dropout 0.75 + Leaky ReLU \\
\hline CNN & $\mathbf{0 . 5 8 7}$ & 0.783 & 0.406 & 0.593 \\
\hline LSTM & 0.534 & $\mathbf{0 . 8 0 5}$ & $\mathbf{0 . 4 8 5}$ & $\mathbf{0 . 6 0 9}$ \\
\hline Bi-LSTM & 0.534 & 0.772 & 0.480 & 0.595 \\
\hline Dropout 0.99 + Leaky ReLU \\
\hline CNN & 0.138 & 0.565 & 0.270 & 0.324 \\
\hline LSTM & $\mathbf{0 . 5 5 5}$ & $\mathbf{0 . 7 9 5}$ & 0.362 & $\mathbf{0 . 5 7 1}$ \\
\hline Bi-LSTM & 0.543 & 0.753 & $\mathbf{0 . 3 9 5}$ & 0.563 \\
\hline
\end{tabular}

\section{F. Hidden Units}

Dalam Tabel X, akurasi dapat ditingkatkan dengan penambahan hidden units. Pada model classifier LSTM, akurasi bertambah 3\% dari 60,2\% menjadi 63\%. Model classifier Bi-LSTM pun mengalami peningkatan sebesar $0,6 \%$ menjadi $64 \%$.

Dibandingkan dengan penelitian terakhir mengenai stance classification dengan deep learning [16], penelitian ini memperoleh peningkatan F1-score sebesar 3,3\% menjadi $64 \%$ dari $60,66 \%$. Perbandingan ini hanya berdasarkan hasil uji coba dengan metode pemodelan kalimat rata-rata dan classifier LSTM pada penelitian sebelumnya. Klaim dan judul terkait dalam dataset penelitian sebelumnya berjumlah 3.954 judul. Sementara itu, penelitian ini memiliki total 3.500 judul dengan jumlah klaim yang sama dengan penelitian sebelumnya yakni 500. Kedua dataset sama-sama memiliki tiga kelas output dan berdistribusi sekitar $30 \%$ per kelas.

TABEL X

HASIL UJI COBA HIDDEN UNITS

\begin{tabular}{|l|l|l|l|l|}
\hline Hidden Units & F1 for & $\begin{array}{l}\text { F1 } \\
\text { observing }\end{array}$ & $\begin{array}{l}\text { F1 } \\
\text { against }\end{array}$ & $\begin{array}{l}\text { F1 } \\
\text { Macro }\end{array}$ \\
\hline LSTM & \multicolumn{5}{|l|}{} \\
\hline $\mathbf{2 0 0}$ & $\mathbf{0 . 5 8 9}$ & $\mathbf{0 . 8 0 3}$ & $\mathbf{0 . 5 0 3}$ & $\mathbf{0 . 6 3 0}$ \\
\hline 100 & 0.570 & 0.794 & 0.440 & 0.602 \\
\hline 50 & 0.566 & 0.792 & 0.496 & 0.619 \\
\hline Bi-LSTM & $\mathbf{0 . 5 8 8}$ & $\mathbf{0 . 8 1 1}$ & $\mathbf{0 . 5 2 4}$ & $\mathbf{0 . 6 4 0}$ \\
\hline $\mathbf{2 0 0}$ & 0.562 & 0.811 & 0.523 & 0.634 \\
\hline 100 & 0.578 & 0.809 & 0.522 & 0.637 \\
\hline 50 &
\end{tabular}

Akan tetapi, F1-score model sebesar $64 \%$ ini masih dibawah F1-score penelitian Kochkina [22] sebesar 78,4\%. Penelitian tersebut menggunakan dataset 5568 tweet, dengan empat kelas output. Distribusi tweet per kelas S:D:Q:C adalah 1004:415:464:3685.

\section{KESIMPULAN}

Stance classification berbahasa Indonesia lebih akurat dilakukan dengan fastText dibandingkan dengan Word2Vec. Word embedding fastText sebaiknya digunakan dengan vektor pre-trained wiki.id.bin untuk stance classification tanpa fitur. Akan tetapi, gunakan cc.id.300.bin bila terdapat informasi fitur kalimat dan post. Dalam memilih classifier, CNN dan Bi-LSTM adalah dua pilihan terbaik. Terutama bila dilakukan pengaturan hidden units pada Bi-LSTM. Penambahan fitur sendiri tidak cukup dengan mencatutkan informasi tanda tanya saja. Perlu ditambahkan informasi ada atau tidaknya kata negatif dalam setiap kalimat dan nilai cosine similarity kalimat klaim dan reaksi. Akan tetapi, tidak perlu menambahkan informasi jumlah like dan comment pada post yang justru memperburuk akurasi model. Nilai dropout yang paling efektif adalah 0,5 dengan activation function ReLU. Diperlukan pula pengaturan hidden units agar tidak terlalu sedikit sehingga model dapat menjadi lebih akurat. Penelitian ini dapat dikembangkan lagi pada eksplorasi efek fitur kalimat dan metadata media sosial lain terhadap performa. Pemahaman makna kalimat juga dapat dikembangkan dengan pendekatan atensi dan pengaruhnya pada akurasi klasifikasi stance.

\section{DAFTAR PUSTAKA}

[1] D. Goldie, M. Linick, H. Jabbar, and C. Lubienski, "Using Bibliometric and Social Media Analyses to Explore the 'Echo Chamber' Hypothesis," Educ. Policy, vol. 28, no. 2, pp. 281-305, 2014, doi: 10.1177/0895904813515330.

[2] S. Jacobson, E. Myung, and S. L. Johnson, "Open media or echo chamber: the use of links in audience discussions on the Facebook Pages of partisan news organizations," Inf. Commun. Soc., vol. 19, no. 7, pp. 875-891, 2016, doi: 10.1080/1369118X.2015.1064461.

[3] J. J. Van Bavel and A. Pereira, "The Partisan Brain: An IdentityBased Model of Political Belief," Trends Cogn. Sci., vol. 22, no. 3 , 
pp. 213-224, 2018, doi: 10.1016/j.tics.2018.01.004.

[4] F. Zollo and W. Quattrociocchi, "Misinformation Spreading on Facebook," pp. 177-196, 2018, doi: 10.1007/978-3-319-77332-2_10.

[5] C. Shao, G. L. Ciampaglia, O. Varol, K. C. Yang, A. Flammini, and F. Menczer, "The spread of low-credibility content by social bots," Nat. Commun., vol. 9, no. 1, 2018, doi: 10.1038/s41467-018-06930-7.

[6] H. Allcott and M. Gentzkow, "Social Media and Fake News in the 2016 Election,” J. Econ. Perspect., vol. 31, no. 2, pp. 211-236, 2017, doi: 10.1257/jep.31.2.211.

[7] C. Reuter, S. Stieglitz, and M. Imran, "Social media in conflicts and crises," Behav. Inf. Technol., vol. 39, no. 3, pp. 241-251, 2020, doi: 10.1080/0144929X.2019.1629025.

[8] M. Roy, N. Moreau, C. Rousseau, A. Mercier, A. Wilson, and L. Atlani-Duault, "Ebola and Localized Blame on Social Media: Analysis of Twitter and Facebook Conversations During the 20142015 Ebola Epidemic," Cult. Med. Psychiatry, vol. 44, no. 1, pp. 5679, 2020, doi: 10.1007/s11013-019-09635-8.

[9] S. Sommariva, C. Vamos, A. Mantzarlis, L. U. L. Đào, and D. Martinez Tyson, "Spreading the (Fake) News: Exploring Health Messages on Social Media and the Implications for Health Professionals Using a Case Study," Am. J. Heal. Educ., vol. 49, no. 4, pp. 246-255, 2018, doi: 10.1080/19325037.2018.1473178.

[10] S. M. Mohammad, P. Sobhani, and S. Kiritchenko, "Stance and Sentiment in Tweets," vol. 0, no. 0, 2016, [Online]. Available: http://arxiv.org/abs/1605.01655.

[11] T. Mikolov, K. Chen, G. Corrado, and J. Dean, "Efficient Estimation of Word Representations in Vector Space," ICLR Work., pp. 1-12, 2013, [Online]. Available: http://arxiv.org/abs/1301.3781.

[12] R. Collobert, J. Weston, L. Bottou, M. Karlen, K. Kavukcuoglu, and P. Kuksa, "Natural Language Processing (Almost) from Scratch," J. Mach. Learn. Res., vol. 12, pp. 2493-2537, 2011, doi: 10.1109/CIC.2017.00050.

[13] Y. Kim, "Convolutional neural networks for sentence classification," EMNLP 2014 - 2014 Conf. Empir. Methods Nat. Lang. Process. Proc. Conf., pp. 1746-1751, 2014.

[14] S. R. Bowman, G. Angeli, C. Potts, and C. D. Manning, "A large annotated corpus for learning natural language inference," Conf. Proc. - EMNLP 2015 Conf. Empir. Methods Nat. Lang. Process., pp. 632642, 2015, doi: 10.18653/v1/d15-1075.

[15] R. Jannati, R. Mahendra, C. W. Wardhana, and M. Adriani, "Stance Classification Towards Political Figures on Blog Writing," Proc. 2018 Int. Conf. Asian Lang. Process. IALP 2018, pp. 96-101, 2019, doi: 10.1109/IALP.2018.8629144.

[16] E. I. Setiawan, A. Ferdianto, J. Santoso, Y. Kristian, S. Sumpeno, and M. H. Purnomo, "Analisis Pendapat Masyarakat terhadap Berita Kesehatan Indonesia menggunakan Pemodelan Kalimat berbasis LSTM ( Indonesian Stance Analysis of Healthcare News using Sentence Embedding," J. Nas. Tek. Elektro dan Teknol. Inf., vol. 9 , no. 1 , pp. 8-17, 2020.

[17] P. Bojanowski, E. Grave, A. Joulin, and T. Mikolov, "Enriching Word Vectors with Subword Information," Trans. Assoc. Comput. Linguist., vol. 5, pp. 135-146, 2017, doi: 10.1162/tacl_a_00051.

[18] A. Graves and J. Schmidhuber, "Framewise Phoneme Classification with Bidirectional LSTM Networks," Proceedings. 2005 IEEE Int. Jt. Conf. Neural Networks, 2005., vol. 4, pp. 2047-2052, 2005.

[19] M. García Lozano, H. Lilja, E. Tjörnhammar, and M. Karasalo, "Mama Edha at SemEval-2017 Task 8: Stance Classification with CNN and Rules," Proc. 11th Int. Work. Semant. Eval., pp. 481-485, 2018, doi: 10.18653/v1/s17-2084.

[20] I. Sutskever, O. Vinyals, and Q. V. Le, "Sequence to sequence learning with neural networks," Adv. Neural Inf. Process. Syst., vol. 4, no. January, pp. 3104-3112, 2014.

[21] W.-F. Chen and L.-W. Ku, "UTCNN: a Deep Learning Model of Stance Classificationon on Social Media Text," Proc. COLING 2016 , 26th Int. Conf. Comput. Linguist. Tech. Pap., pp. 1635-1645, 2016, [Online]. Available: http://arxiv.org/abs/1611.03599.

[22] E. Kochkina, M. Liakata, and I. Augenstein, "Turing at SemEval2017 Task 8: Sequential Approach to Rumour Stance Classification with Branch-LSTM," no. 2016, pp. 475-480, 2018, doi: $10.18653 / \mathrm{v} 1 / \mathrm{s} 17-2083$.

[23] K. Shalini, M. Anand Kumar, and K. Soman, Deep-Learning-Based Stance Detection for Indian Social Media Text, vol. 545. Springer Singapore, 2019.

[24] M. Thomas, B. Pang, and L. Lee, "Get out the vote: Determining support or opposition from Congressional oor-debate transcripts," In Proc. of EMNLP, no. July, pp. 327-335, 2006.

[25] K. Hasan and V. Ng, "Stance Classification of Ideological Debates: Data , Models , Features , and Constraints," Proc. SIGDIAL 2013 Conf., no. October, pp. 1348-1356, 2013.
[26] B. Riedel, I. Augenstein, G. P. Spithourakis, and S. Riedel, "A simple but tough-to-beat baseline for the Fake News Challenge stance detection task," pp. 1-6, 2017, [Online]. Available: http://arxiv.org/abs/1707.03264.

[27] A. Hanselowski et al., "A Retrospective Analysis of the Fake News Challenge Stance Detection Task," 2018, [Online]. Available: http://arxiv.org/abs/1806.05180.

[28] I. Augenstein, T. Rocktäschel, A. Vlachos, and K. Bontcheva, "Stance Detection with Bidirectional Conditional Encoding," pp. 876-885, 2016, doi: 10.18653/v1/d16-1084.

[29] I. Habernalt and I. Gurevych, "Which argument is more convincing? Analyzing and predicting convincingness of Web arguments using bidirectional LSTM," 54th Annu. Meet. Assoc. Comput. Linguist. ACL 2016 - Long Pap., vol. 3, pp. 1589-1599, 2016, doi: 10.18653/v1/p161150 .

[30] D. Mrowca and E. Wang, "Stance detection for fake news identification," pp. 1-12, 2017.

[31] Y. Bengio, R. Ducharme, P. Vincent, and C. Jauvin, "A Neural Probabilistic Language Model," J. Mach. Learn. Res., vol. 3, pp. 1137-1155, 2003, doi: 10.1080/1536383X.2018.1448388

[32] A. Joulin, E. Grave, P. Bojanowski, and T. Mikolov, "Bag of tricks for efficient text classification," 15th Conf. Eur. Chapter Assoc. Comput. Linguist. EACL 2017 - Proc. Conf., vol. 2, pp. 427-431, 2017, doi: 10.18653/v1/e17-2068.

[33] I. Santos, N. Nedjah, and L. de Macedo Mourelle, "Sentiment analysis using convolutional neural network with fastText embeddings," pp. 1-5, 2018, doi: 10.1109/la-cci.2017.8285683.

[34] R. Kiros et al., "Skip-thought vectors," Adv. Neural Inf. Process. Syst., vol. 2015-Janua, no. 786, pp. 3294-3302, 2015.

[35] L. Logeswaran and H. Lee, "An efficient framework for learning sentence representations," 6th Int. Conf. Learn. Represent. ICLR 2018 - Conf. Track Proc., pp. 1-16, 2018.

[36] Y. Adi, E. Kermany, Y. Belinkov, O. Lavi, and Y. Goldberg, "Finegrained analysis of sentence embeddings using auxiliary prediction tasks," 5th Int. Conf. Learn. Represent. ICLR 2017 - Conf. Track Proc., pp. 1-13, 2019.

[37] J. Wieting, M. Bansal, K. Gimpel, and K. Livescu, "Towards universal paraphrastic sentence embeddings," 4th Int. Conf. Learn. Represent. ICLR 2016 - Conf. Track Proc., pp. 1-19, 2016.

[38] F. Z. Tala, "A Study of Stemming Effects on Information Retrieval in Bahasa Indonesia," M.Sc. Thesis, Append. D, vol. pp, pp. 39-46, 2003.

[39] Y. Zhang and B. Wallace, "A Sensitivity Analysis of (and Practitioners' Guide to) Convolutional Neural Networks for Sentence Classification," 2015, [Online]. Available: http://arxiv.org/abs/1510.03820.

Ernest Lim adalah lulusan S1 jurusan Aristektur di Universitas Katolik Parahyangan pada tahun 2016. Ernest kemudian melanjutkan studi S2 Teknologi Informasi di STTS sejak tahun 2018.

Esther Irawati Setiawan menyelesaikan studi S1 di program Teknik Informatika STTS pada tahun 2006. Menyelesaikan studi master Teknologi Informasi STTS pada tahun 2010. Minat penelitian pada bidang Social Network Analysis dan Web Mining.

Joan Santoso menyelesaikan studi S1 Teknik Informatika di STTS pada tahun 2011. Menyelesaikan studi S2 Teknologi Informasi di STTS pada tahun 2013. Minat penelitian pada bidang computational linguistics, information extraction, machine learning, dan big data processing. 